influenced by treatment and progressed till the cornea quickly became vascular and abraded over the central area. On the 20th 0.25 cubic centimetre of a 1 in 1000 solution of Koch's old tuberculin was injected subcutaneously. This was followed by a rise in temperature and resulted in great improvement in the condition of the right eye, though the left remained unchanged. Subsequently the old tuberculin was again injected twice, the first time to the amount of 0.25 cubic centimetre and the second time to the amount of 0.5 cubic centimetre, and by the end of Norember the right eye was almost quite recovered, while in the left the discharge had begun to lessen. After that date the improvement in the latter was steady but there remains as a result of the Calmette instillation a considerable opacity of the centre of the cornea, and in consequence the vision is seriously impaired.

Glasgow.

\section{NOTE ON A CASE OF POISONING BY GELSEMIUM.}

By JoHN BELL, L.R.C.P. LOND., M.R.C.S. ENG.,

SUPERINTENDENT OF THE GOVERNMENT CIVIL HOSPITAL, HONG-KONG

As "Taylor's Medical Jurisprudence" states that this vegetable poison has never been the cause of a criminal charge the following case may be of interest to the readers of THE LANCET, more especially as the defendant's barrister with "Taylor" in his hand, made much of this fact. The case was tried at the Criminal Sessions on Jan. 20th, 1908 before Sir Francis Piggott, C.J. The woman was found guilty and sentenced to death. The brief facts were that in consequence of a love affair having led to a disturbance she boiled some herbs and gave them to her husband as "cooling medicine" and he died shortly afterwards. The man had his food about 5.15 P.M.; the poison was administered about 6 or 6.15 P.M. The first symptoms appeared about half an hour afterwards and he died about three and a quarter hours after taking the "cooling medicine."

Mr. F. Browne, the Government analyst. identified the herbs as "gelsemium elegans" and extracted one-sixth of a grain of gelseminine from the contents of the man's stomach. The woman attempted to commit suicide but recovered. When sent to this hospital at $11.50 \mathrm{P}$ M., four hours after she had taken the poison according to her own story, she was semi-conscious, with dilated pupils insensible to light, and with slight contractions of the muscles, more especially of the upper limb. She was quite well on the next day. inclose the police report.

\section{[INCLOSURE.]}

Western District Police Office, Jan. 21st, 1908. Poisoning Case at No. 59, High-street.

SIR.-On the evening of Nov. 17th, 1907, Cheung Fuk was poisoned by his coneubine, Lam Kiu, alias Mo Ho, at the above address. Cheung Fuk was a foreman stonecutter and contractor and was a Hakka, as probably about 90 per cent. of the stonecutters in this colony are. The concubine had a paramour and both her and the paramour also were Hakkas. At about 1 P.Mr. on Nov. 15th, 1907, Cheung Fuk returned home, and being about three bours earlier than usual found the paramour, $\mathbf{N g}$ Nin, leaving his house after paying a visit to his concubine in his absence. He did not interfere with $\mathrm{Ng} \mathrm{Nin}$, but on entering his house he demanded an explanation from his concubine and as no explanation was forthcoming he assaulted her with an umbrella. .... On Nov. 17th Cheung . uk is said to have returned bome 5.10 P.M., when he had his rice, \&c., and some little time afterwards the concubine boiled some herbs as a cooling medicine for him and the concubine boiled some herbs as a cooling medicine for him and
boiled the poisonous stems and leaves and put into the cooling medicine and gave it to him to drink. We cannot ascertain the exact cine and gave it to him to drink. We eannot ascertain the exact
time he took it, but most probably about 6 P.M. to 6.15 P.M. The concubine in her statement before the court gave the time as 730 P.M. when she gave him the medicine, and stated that he died at 8 P.M. A witness named Cheung Chung (who is decersed's nephew) stated "that when he visited Cheung Fuk at about 7.30 P.M. he found him rolling about on his bed in great pain and that he rolled off' on to the floor, the muscles appeared to be all on the work, twitching and contracting, and the face distorted," and that he died at about 9.30 P.M. The concubine told us " that she took of the poison at about 7.50 P.M.," and when Sergeant Lenaghan entered the house at 11 P.M. " he found her rolling on the floor, she was in a dazed condition, almost unconseious, was perspiring very freely, muscles twitehing, and face distorted, the eves very full and pupils dilated.

1. Cheung Fuk's age was about 50 years.

2. The poison was given with herb tea, not with the food; he, however, had a feed of rice and congee at about 5.15 P.M.

3. Probably about half an hour after taking the poison the symptoms began.

4. As near as I can ascertain he died about three and a quarter hours from the time he took it, or two and three-quarter hours from the tim the symptoms began to show.

The Superintendent, Govt. Civil Hospital.

PS.-This poison is well known to the Hakkas ("O Mŭn Ting " or "Tai Cha Yenk") and is given to pigs and goats as a medicine by them.

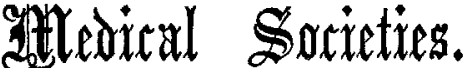

\section{ROYAL SOCIETY OF MEDICINE.}

\section{MEDICAL SECTION.}

Acute Suffocative Catarrh.-A Case of Acute Ulcerative Colitis with some Unusual Symptoms.

A MEETING of this section was held on Feb. 25th, Dr. S. J. GEE, the President, being in the chair.

Dr. SAMUEL WEST read a paper on Acute Suffocative Catarrh, He said that the acute suffocative catarrh of Laennec was still but little recognised-an acute catarrh of sudden onset, with suffocative dyspncea, lasting from 24 to 48 hours. If not fatal it ran the course of an acute bronchitis. He cited a case which occurred in a young man, aged 23 years. In 24 hours from a condition of perfect health the patient passed into a state of urgent dyspnœe with considerable cyanosis and looked likely to die. Rhonchus and sibilus were the only physical signs and the tempera. tnre was raised to $101^{\circ} \mathrm{F}$. In 24 hours more the urgent dyspncea passed off. A little expectoration was then brought up and was found to contain a few pneumococci buts a large number of diphtheroid bacilli of uncertain nature. The case ran a slow and tedious course towards recovery. Two other bacteriological examinations, made at intervals, showed the same bacilli. It was possible that the attack depended upon the bacilli and their wide dissemination through the bronchial tubes. The following conditions were such as were either liable to be confused with true suffocative catarrh or presented interesting relations with it: 1 . Acute suffocative pulmonary cedema, or as it had been called acute non-inflammatory congestion of the lungs. Of this two instances were given with antecedent morbus cordis, one in the course of mitral disease and the other of aortic disease. It also occurred without antecedent morbus cordis, as in the course of hyperpyrexia or of malignant or septic fevers. 2. Acute inflammatory congestions. Capillary bronchitis and secondary broncho-pneumonia gave rise to little confusion. Primary broncho-pneumonia, or acute disseminated pneumococcal pneumonia, was very closely allied to suffocative catarrh. There was a form of acute pneumococcal bronchitis, and indeed suffocative catarrh might be, as the case described suggested, of pneumococcal or other bacterial origin. In the early congestive stage of acute pneumonia the dyspncea might be urgent and the whole lung be affected. The general congestion passed off as the local lesion developed. That might be attended even with considerable bæmoptysis. 3. Collateral fluxion or palmonary failure where one or both lungs were much taxed. The extra work might easily and rapidly pass into overwork and the failure was marked by the signs of congestion or bronchitis-a condition of gravity which if it conld not be relieved at once was rapidly fatal Pulmonary failure might arise on the opposite side in a case of pleuritic effusion or pneumothorax in both lungs in a case of abdominal distension--e.g., ascites, acute peritonitis, or tympanites, and in the other parts of the lungs in a case of acute pneumonia. Laennec's acute suffocative catarrì was a peculiar and characteristic affection and might, as the case recited suggested, be due to a widespreau bacterial infection - The PRESIDENT described how im. pressed he had been with the first case he had met. with in his practice of acute suffocative catarrh described by Laennec, and added that it had made him very careful in expressing an opinion of the future course of any case of bronchitis at the beginning of the attack. Dr. F. J. WETHERED narrated a case of a man who died 48 hours after the administration of ether for an operation with symptoms similar to those described by Dr. West. The question was, Was there any association between the two? In regard to Laennec's acute suffocative catarrh being due to bacterial infection, Dr. Wethered asked Dr. West to express an opinion on the case of three men who had cleaned out a filthy cesspool and who within a few hours were seized with symptoms of urgent dyspncea and died within 24 hours.Dr. W. EWART suggested artificial respiration in the prone position as an early treatment in cases of acute suffocative catarrh.-Dr. WEST, in reply, suggested that the explanation of the death of the patient mentioned by Dr. Wethered with acate pulmonary symptoms after the administration of 